\title{
HUBUNGAN MATA KULIAH PENDIDIKAN KEWARGANEGARAAN DENGAN PENINGKATAN WAWASAN KEBANGSAAN DAN SEMANGAT NASIONALISME MAHASISWA
}

\author{
${ }^{1}$ Fitri Silvia Sofyan, ${ }^{2}$ Dadang Sundawa \\ ${ }^{1}$ Mahasiswa Dep. Pendidikan Kewarganegaraan, SPs, UPI, e-mail: fs.saybia@mail.com \\ ${ }^{2}$ Dosen Dep. Pendidikan Kewarganegaraan, SPs, UPI.
}

\begin{abstract}
This research is purposed to procure representation about correlations between civic education courses with the students' insight into nationalism and the students' spirit of nationalism in STKIP Garut. This study used quantitative approach with a correlation study method. The data of this study was obtained through questionnaires and tests given to students in STKIP Garut. Researcher revealed that: 1. The implementation of civic education as a general basic course included in personality development course in STKIP Garut had been implemented very well and was able to make a significant contribution, which is in accordance to civic education's goal itself. 2. Students in STKIP Garut were believed to have a good insight into nationalism and a strong nationalism. 3. The application of civic education courses as a general basic course has a strong correlation and a great influence on the improvement of the students' insight into nationalism and the spirit of nationalism in STKIP Garut.
\end{abstract}

Keywords: Civic education course, nationality, insight on nationalism, spirit of nationalism, STKIP Garut.

\section{PENDAHULUAN}

Pendidikan Kewarganegaraan merupakan salah satu bidang kajian dalam konteks pendidikan nasional yang memiliki peran strategis untuk meningkatkan kembali wawasan kebangsaan dan semangat nasionalisme mahasiswa. Karena itu, untuk memperkuat peran Pendidikan Kewarganegaraan, maka pemerintah mewajibkan diberikan pada setiap satuan pendidikan termasuk perguruan tinggi. Sebagaimana dalam pasal 37 ayat (1) Undang-Undang No.20 Tahun 2003 tentang Sistem Pendidikan Nasional bahwa "Pendidikan Kewarganegaraan dimaksudkan untuk membentuk peserta didik menjadi manusia yang memiliki rasa kebangsaan dan cinta tanah air". Jika dikaji lebih jauh maka pemerintah melalui undangundang tersebut memiliki tujuan menyiapkan generasi muda (mahasiswa) agar memiliki wawasan kebangsan dan semangat nasionalisme, karena mahasiwa merupakan kader bangsa yang akan meneruskan tonggak kepemimpinan bangsa dan negara Indonesia. Karena itu, negara bertanggung jawab untuk mempersiapkan generasi muda/mahasiswa yang memiliki wawasan kebangsaan yang tinggi dan juga memiliki semangat nasionalisme dalam kehidupan berbangsa dan bernegara. Sebagaimana Winataputra (2014) :

Secara holistic pendidikan kewarganegaraan bertujuan agar setiap warga Negara muda (young citizens) memiliki rasa kebangsaan dan cinta tanah air dalam konteks nilai dan moral Pancasila, nilai dan norma Undang-Undang Dasar Negara Republik Indonesia Tahun 1945, nilai dan komitmen Bhinneka tunggal Ika, dan komitmen bernegara kesatuan Republik Indonesia. Oleh karena itu secara sadar dan terencana peserta didik sesuai dengan perkembangan psikologis 
dan konteks kehidupannya secara sistemik difasilitasi untuk belajar berkehidupan demokrasi secara utuh, yakni belajar tentang demokrasi (learning about democracy), belajar dalam iklim dan melalui proses demokrasi (learning through democracy), dan belajar untuk membangun demokrasi (learning for democracy).

Kondisi kehidupan berbangsa dan bernegara Indonesia saat ini mengalami kemunduran dalam pemahaman wawasan kebangsaan dan semangat nasionalisme. Hal ini generasi muda mempunyai peranan penting dalam menjaga kelangsungan hidup bangsa dan negara. Karena itu, kesadaran awal yang harus kita tahu bahwa dalam penghayatan rasa kebangsaan dan cinta tanah air adalah kenyataan bahwa kita telah menjadi bagian tetap dari bangsa ini, bangsa Indonesia. Disinilah tempat kita lahir, berpijak, hidup, bertumbuh dan berkembang, serta (mungkin saja) kita nanti akan menghembuskan nafas terakhir di tanah air ini. Oleh karenanya, demi membangkitkan kembali semangat nasionalisme generasi muda kita membutuhkan komitmen untuk meneguhkan semangat persatuan dan kesatuan dengan memegang penuh semboyan negara, yakni "Bhinneka Tunggal Ika”. Jadi jika landasan rasa kebangsaan di waktu yang lampau lebih didasari oleh rasa kebersamaan masa lalu, sekarang dan ke depan rasa kebangsaan harus dilandasi oleh kesamaan pandangan tentang masa depan bersama yang akan kita tuju sebagai "suatu bangsa" (one of nation).

Penanaman dan pengembangan wawasan kebangsaan dan nasionalisme menuntut pendidikan kewarganegaraan agar mampu mewujudkan apa yang menjadi tujuan dari pendidikan kewarganegaraan itu sendiri. Kita harus mampu mempererat persatuan dan kesatuan bangsa di atas segala perbedaan, baik perbedaan suku, ras, maupun agama. Sejalan dengan pemaparan di atas Asep Mahpudz (1996, hlm.281) mengatakan bahwa :

Untuk membangun nasionalisme generasi muda sebagai wujud pendidikan kewarganegaraan adalah ungkapan perasaan senasib sepenanggungan dalam lingkup bangsa dalam bentuk kepedulian dan kepekaan akan masalah-masalah yang dihadapi bangsa, termasuk di dalamnya masalah yang berkaitan dengan rasa solidaritas sebangsa dan setanah air. Setidaknya yang dibutuhkan adalah menyangkut aspek pembinaan nilai-nilai kepribadian dan aspek peningkatan pengetahuan wawasan kebangsaan. Oleh karena itu, upaya pembinaan nasionalisme Indonesia pada masa sekarang selayaknya mengutamakan pandangan dan sikap antisipotoris, berupa pembinaan kemampuan untuk memperhitungkan perkembangan yang akan terjadi dimasa depan. Artinya dibutuhkan penanaman sikap menghadapi segala situasi baru yang belum pernah terjadi dalam kehidupan suatu masyarakat atau suatu bangsa.

Pendidikan kewarganegaraan di perguruan tinggi merupakan sumber nilai dan pedoman dalam pengembangan dan penyelengaraan program studi, guna mengantarkan mahasiswa memantapkan kepribadiannya sebagai manusia seutuhnya. Hal ini berdasarkan pada suatu realitas yang dihadapi, bahwa mahasiswa adalah sebagai generasi bangsa yang harus memiliki visi intelektual, religius, berkeadaban, berkemanusiaan dan cinta tanah air dan bangsanya. Dengan adanya mata kuliah Pendidikan Kewarganegaraan diharapkan dapat membantu mahasiswa memantapkan kepribadiannya, agar secara konsisten mampu mewujudkan nilai-nilai dasar Pancasila, rasa kebangsaan dan cinta tanah air dalam menguasai, menerapkan dan mengembangkan ilmu pengetahuan, teknologi dan seni dengan rasa tanggung jawab dan bermoral. Berkaitan 
dengan itu mahasiswa diharapkan akan mampu untuk menjaga dan meneruskan citacita pembangunan bangsa dengan sungguhsungguh mencintai bangsanya sendiri, dengan tidak membeda-bedakan setiap suku, ras, maupun agama yang mendiami di bumi pertiwi Indonesia. Dengan wawasan kebangsaan dan juga semangat nasionalisme maka hal ini diharapkan agar kita dapat menjaga keutuhan Negara agar tidak terpecah belah.

Sekolah Tinggi Keguruan dan Ilmu Pendidikan Garut merupakan salah satu perguruan tinggi yang berada di wilayah Kabupaten Garut. Oleh karena itu, Sekolah Tinggi Keguruan dan Ilmu Pendidikan Garut sebagai salah satu perguruan tinggi yang melaksanakan kegiatan mata kuliah pendidikan kewarganegaraan sangat mendukung langkah-langkah yang diambil oleh pemerintah untuk mengembangkan kehidupan bernegara dan berbangsa dalam kalangan generasi muda dan mahasiswa pada khususnya. Pemahaman akan wawasan kebangsaan dan juga semangat nasionalisme sudah terintegrasi dalam mata kuliah Pendidikan Kewarganegaraan.

Berdasarkan identifikasi masalah, maka dirumuskan permasalahannya yaitu adakah korelasi yang signifikan antara mata kuliah Pendidikan Kewarganegaraan dengan peningkatan wawasan kebangsaan dan semangat nasionalisme mahasiswa di lingkungan Sekolah Tinggi Keguruan dan Ilmu Pendidikan Kabupaten Garut. Dari rumusan permasalah tersebut, selanjutnya dirinci pertanyaan penelitiannya sebagai berikut : 1) Bagaimana gambaran penerapan mata kuliah Pendidikan Kewarganegaraan (PKn) yang dilaksanakan di Sekolah Keguruan dan Ilmu Pendidikan Garut di Kabupaten Garut? 2) Bagaimana gambaran pemahaman wawasan kebangsaan dan semangat nasionalisme mahasiswa di lingkungan Sekolah Tinggi
Keguruan dan Ilmu Pendidikan Garut di Kabupaten Garut? 3) Adakah korelasi antara mata kuliah Pendidikan Kewarganegaraan dengan peningkatan wawasan kebangsaan dan semangat nasionalisme mahasiswa di Sekolah Tinggi Keguruan dan Ilmu Pendidikan Garut di Kabupaten Garut?

Tujuan penelitian berkaitan erat dengan permasalahan penelitian. Tujuan penelitian berisi tentang rumusan hasil yang akan dicapai dalam penelitian yang merupakan jawaban dari pertanyaan penelitian yang dilakukan. Adapun tujuan umum yang ingin dicapai dalam penelitian ini adalah untuk memperoleh gambaran mengenai korelasi Pendidikan Kewarganegaraan dengan peningkatan wawasan kebangsaan dan semangat nasionalisme mahasiswa. di Sekolah Tinggi Keguruan dan Ilmu Pendidikan Kabupaten Garut. Sedangkan tujuan khusus penelitian dapat diuraikan sebagai berikut : 1) Untuk mendeskripsikan gambaran penerapan mata kuliah Pendidikan Kewarganegaraan (PKn) yang dilaksanakan di Sekolah Keguruan dan Ilmu Pendidikan Garut di Kabupaten Garut. 2) Untuk mendeskripsikan gambaran pemahaman wawasan kebangsaan dan semangat nasionalisme mahasiswa di lingkungan Sekolah Tinggi Keguruan dan Ilmu Pendidikan Garut di Kabupaten Garut. 3) Untuk mengetahui adakah korelasi Pendidikan Kewarganegaraan (PKn) dengan peningkatan wawasan kebangsaan dan semangat nasionalisme dalam perkuliahan Pendidikan Kewarganegaraan (PKn) Sekolah Tinggi Keguruan dan Ilmu Pendidikan Garut di Kabupaten Garut.

\section{METODE PENELITIAN}

Metode penelitian ini adalah metode korelasional dengan menggunakan pendekatan kuantitatif, yakni mendeskripsikan mengenai 
hubungan korelasi penerapan Pendidikan Kewarganegaraan dengan peningkatan wawasan kebangsaan dan semangat nasionalisme mahasiswa. Dalam penelitian ini peneliti berkeinginan mengungkap fenomenafenomena obyektif dan dikaji secara kuantitatif dan peneliti ingin menjawab pertanyaan penelitian menggunakan pengukuran yang cermat terhadap variabel-variabel penelitian.

Nana Sudjana dan Ibrahim (2007:77) menjelaskan mengenai pengertian dari metode penelitian korelasional, "studi korelasi mempelajari hubungan dua variabel atau lebih, yakni sejauh mana variasi dalam satu variabel berhubungan dengan variasi dalam variabel lain. Hal ini senada dengan Nana Syaodih (2007:79) "studi hubungan (associational study) disebut juga studi korelasional (correlational study), meneliti hubungan antara dua hal, dua variabel atau lebih". Tujuan penelitian ini untuk mendeteksi sejauhmana variasi-variasi pada suatu faktor berkaitan dengan variasi-variasi pada saat atau lebih faktor lain berdasarkan pada koefisien korelasi. Dalam penelitian ini peneliti ingin melihat hubungan dua variabel tanpa coba merubah atau mengadakan perlakuan terhadap variabel-variabel tersebut. Berkaitan hal tersebut Kountur (2009:54-55) mengemukakan bahwa "penelitian korelasi adalah penelitian yang mencoba melihat hubungan antara beberapa variabel sebagaimana adanya tanpa perlakuan". Melihat apakah mungkin perubahan satu variabel berhubungan dengan perbahan variabel lainnya.

Sampel penelitian ini adalah sebagian dari seluruh mahasiswa di lingkungan Sekolah Tinggi Keguruan dan Ilmu Pendidikan Garut. Prosedur pemilihan sampel (sampling) dalam penelitian ini adalah yaitu random sampling . Sedangkan metode yang dipakai yaitu metode proportionate stratified random sampling.
Sugiono (2010, hal.82) berpandangan bahwa "teknik ini digunakan bila populasi mempunyai anggota/unsur yang tidak homogen dan bersrata secara proporsional". Hal tersebut sesuai dengan unit sampel yang ada pada populasi penelitian ini. Populasi penelitian ini ialah mahasiswa Sekolah Tinggi Keguruan dan Ilmu Pendidikan Garut yang terdiri dari program studi Pendidikan Kewarganegaraan, Pendidikan Bahasa dan Sastra Indonesia, Pendidikan Bahasa Inggris, Pendidikan Matematika, Pendidikan Biologi, dan Pendidikan Teknologi dan Ilmu Komputer.

Dengan menggunakan tabel penentuan jumlah sampel dari populasi tertentu dengan taraf kesalahan 5\%, bila jumlah populasi 2.991, dengan kesalahan 5\%, maka jumlah sampelnya $=312$. Karena populasi bersrata, maka sampelnya pun berstrata. Stratanya ditentukan menurut program studi yang ada. Dengan demikian masing-masing sampel untuk setiap program studi harus proporsional sesuai dengan populasi. Berdasarkan perhitungan dengan cara berikut ini jumlah sampel untuk sampel untuk mahasiswa program studi Pendidikan Bahasa dan Sastra Indonesia $=65$, Pendidikan Pancasila dan Kewarganegaraan = 31, Pendidikan Bahasa dan Sastra Inggris = 86, Pendidikan Biologi $=47$, Pendidikan Matematika $=68$, dan Pendidikan Teknologi dan Ilmu Komputer $=15$.

$\begin{aligned} \text { Pend. Bhs Indonesia } & =621: 2991 \text { X } 312 \\ & =64,7=65 \\ & =296: 2991 \text { X } 312 \\ & =30,8=30 \\ \text { Pend. Bahasa Inggris } & =823: 2991 \text { X } 312 \\ & =85,8=86 \\ \text { Pend. Biologi } & =455: 2991 \text { X } 312 \\ \text { Pend. Matematika } & =47,4=47 \\ \text { Pend. TIK } & =656: 2991 \text { X } 312 \\ & =140: 2991 \text { X } 312 \\ & =14,6=15\end{aligned}$




\section{HASIL DAN PEMBAHASAN}

\section{Penerapan Mata Kuliah PKn di STKIP Garut}

Berdasarkan hasil perhitungan terhadap prosentase skor masing-masing indikator dapat diketahui bahwa berdasarkan uji statistik, penerapan mata kuliah di STKIP Garut tergolong ke dalam sangat baik. Hasil pengukuran statistik ini didukung oleh kondisi di lapangan dimana Program Studi Pendidikan Pancasila dan Kewarganegaraan sebagai induk pelaksanaan penerapan mata kuliah PKn sebagai MKDU di lingkungan STKIP Garut sudah mampu menerapkan mata kuliah ini dengan baik, sehingga apa yang menjadi tujuan dari mata kuliah inipun dapat tercapai.

Secara paradigmatik Winataputra (2001) mengemukakan bahwa Pendidikan Kewarganegaraan memiliki tiga komponen, "yakni (1) kajian ilmiah pendidikan ilmu kewarganegaraan; (2) program kurikuler Pendidikan Kewarganegaraan; dan (3) gerakan sosial-kultural kewarganegaraan, yang secara koheren bertolak dari esensi dan bermuara pada upaya pengembangan pengetahuan kewarganegaraan (civic knowledge), nilai, sikap dan watak kewarganegaraan (civic disposition), dan keterampilan kewarganegaraan (civic skill)".

Pendidikan Kewarganegaraan dalam konteks domain kurikuler merupakan penempatan Pendidikan Kewarganegaaran dalam pendidikan formal (jenjang SD sampai perguruan tinggi) dan juga dalam pendidikan nonformal. Dalam domain ini Pendidikan Kewarganegaraan berfungsi sebagai mata pelajaran yang diterapkan di sekolah dan mata kuliah di perguruan tinggi.

Berdasarkan Undang-Undang RI No. 20 Tahun 2003, tentang Sistem Pendidikan Nasional, serta Surat Keputusan Direktur Jenderal Pendidikan Tinggi Departemen Pendidikan Nasional No. 43/DIKTI/KEP/2006 tentang "Rambu-rambu pelaksanaan Kelompok Mata Kuliah Pengembangan Kepribadian di Perguruan Tinggi”. Terdiri atas mata kuliah pendidikan agama, pendidikan kewarganegaraan dan bahasa Indonesia. Mata kuliah pendidikan kewarganegaraan merupakan bagian dari kelompok mata kuliah pengembangan kepribadian, dengan ketentuan tersebut di atas wajib diberikan di semua fakultas dan jurusan di seluruh perguruan tinggi.

Adapun Hakekat, Visi, Misi, dan Kompetensi Mata Kuliah Pendidikan Kewarganegaraan berdasarkan Keputusan Dirjen Dikti N0.43/DIKTI/KEP/2006 dirumuskan sebagai berikut: Hakekat Mata Kuliah Pendidikan Kewarganegaraan adalah untuk membekali dan memantapkan mahasiswa dengan pengetahuan dan kemampuan dasar hubungan warga negara Indonesia yang Pancasilais dengan negara dan sesama warga negara. Visi Mata Kuliah Pendidikan Kewarganegaraan adalah merupakan sumber nilai dan pedoman dalam pengembangan dan penyelenggaraan program studi, guna mengantarkan mahasiswa memantapkan kepribadiannya sebagai manusia Indonesia seutuhnya. Misi Mata Kuliah Pendidikan Kewarganegaraan adalah untuk membantu mahasiswa memantapkan kepribadiannya agar secara konsisten mampu mewujudkan nilainilai dasar Pancasila, rasa kebangsaan dan cinta tanah air dalam menguasai, menerapkan dan mengembangkan ilmu pengetahuan, teknologi dan seni dengan rasa tanggung jawab. Kompetensi Mata Kuliah Pendidikan Kewarganegaraan adalah diharapkan mahasiswa menjadi ilmuwan yang memiliki rasa kebangsaan dan cinta tanah air, demokratis yang berkeadaban menjadi warga negara yang memiliki daya saing, berdisiplin dan berpartisipasi aktif dalam membangun kehidupan yang damai berdasarkan sistem nilai Pancasila. 
Adapun yang menjadi bahan kajian pendidikan kewarganegaraan menurut Surat Keputusan tersebut meliputi: Filsafat Pancasila; Identitas Nasional; Hak dan Kewajiban Warga Negara; Negara dan Konstitusi; Demokrasi Indonesia; Hak Asasi Manusia dan Rule of Law; Geopolitik Indonesia; Geostrategi Indonesia

Hampir semua orang sepakat karena telah menjadi pengetahuan umum khususnya di kalangan komunitas akademik pendidikan kewarganegaraan (civic/citizenship education) di Indonesia bahkan di negara lain bahwa tujuan pendidikan kewarganegaraan adalah untuk membentuk warga negara yang baik (to be good citizens). Numan Somantri (dalam Wahab dan Sapriya, 2011, hlm.311) melukiskan warga negara yang baik adalah warga negara yang patriotik, toleran, setia terhadap bangsa dan negara, beragama, demokratis ..., Pancasila sejati. Berhubungan dengan penjelasan warga negara yang baik Azis Wahab mengemukakan sebagai berikut:

Warga negara yang baik adalah warga negara yang memahami dan mampu melaksanakan dengan baik hak-hak dan kewajibannya sebagai individu warga negara memiliki kepekaan dan tanggung jawab sosial, mampu memecahkan masalah-masalahnya sendiri dan juga masalah-masalah kemasyarakatan secara cerdas sesuai dengan fungsi dan perannya (socially sensitive, socially responsible, dan socially inteligence), memiliki sikap disiplin pribadi, mampu berpikir kritis kreatif, dan inovatis agar dicapai kualitas pribadi dan perilaku warga negara dan warga masyarakat yang baik (socio civic behavior dan desirable personal qualities) (Wahab dan Sapriya: 2011, hlm.311-312).

Tujuan Pendidikan Kewarganegaraan di perguruan tinggi dirumuskan dalam visi, misi dan kompetensi yang tercantum dalam Kep. Dirjen DIKTI No.43/DIKTI/Kep/2006. Dari apa yang tertuang dalam Surat Keputusan Dirjen Dikti tersebut dapat kita ketahui bahwa substansi pendidikan kewarganegaraan di Perguruan Tinggi, pada hakikatnya yaitu untuk membekali dan memantapkan mahasiswa dengan pengetahuan dan kemampuan dasar hubungan warga negara Indonesia yang Pancasilais dengan negara dan sesama warganegara. Dengan kemampuan dasar diharapkan mahasiswa mampu menerapkan nilai-nilai tersebut dalam kehidupan sehari-hari; memiliki kepribadian yang mantap, berpikir kritis, bersikap rasional, etis, estetis, dan dinamis, berpandangan luas, bersikap demokratis dan berkeadaban.

\section{Pemahaman Wawasan Kebangsaan dan Semangat Nasionalisme Mahasiswa di STKIP Garut}

Sama halnya seperti penerapan mata kuliah PKn, kondisi pemahaman wawasan kebangsaan dan semangat nasionalisme mahasiswa di lingkungan STKIP Garut juga dapat dilihat berdasarkan hasil penghitungan terhadap prosentase skor nilai yang didapat pada variabel $Y_{1}$ dan variabel. Secara statistik, pemahaman wawasan kebangsaan dan semangat nasionalisme mahasiswa di lingkungan STKIP Garut termasuk ke dalam kategori sangat baik, hal ini terlihat dari skor rata-rata yang didapatkan responden dalam pengukuran melalui instrumen tes bertingkat. Hasil pengukuran melalui tes bertingkat yang dihitung secara statistik menunjukkan bahwa pemahaman wawasan kebangsaan dan semangat nasionalisme mahasiswa STKIP Garut berada pada kategori sangat baik.

Pemahaman wawasan kebangsaan dan semangat nasionalisme pada diri individu dipengaruhi oleh banyak hal, namun berdasarkan hasil penelitian pemulis memiliki pandangan bahwa dari sekian banyak hal yang 
mempengaruhi pemahaman wawasan kebangsaan dan semangat nasionalisme, hal yang memiliki pengaruh sangat besar adalah mata kuliah PKn yang sudah ditempuh oleh para mahasiswa di lingkungan STKIP Garut.

Setiap bangsa di dunia memiliki cara pandang terhadap kebangsaan dan tanah airnya masing-masing, dan cara pandang terhadap kebangsaannya itu kemudian disebut sebagai wawasan kebangsaan. Bangsa Indonesia memiliki wawasan kebangsaanya sendiri yang sesuai dengan nilai-nilai Pancasila. Berdasarkan nilai-nilai tersebut bangsa Indonesia memiliki cara pandang untuk melangkah ke depan dalam mencapai tujuan nasional.Maliki (2010, hlm.180) berpendapat bahwa "wawasan kebangsaan adalah cara pandang yang dapat memberi pijakan bagi anak bangsa dalam membangun kohesi sosial dan kesepakatan hidup bersama di tengah negeri yang memiliki ribuan pulau, pluralitas etnis, bahasa, budaya, ideologi informal berserta agama”.

Wawasan Kebangsaan pada hekekatnya merupakan suatu pandangan atau cara pandang yang mencerminkan sikap dan kepribadian bangsa Indonesia yang memiliki rasa cinta tanah air, menjunjung tinggi kesatuan dan persatuan, memiliki rasa kebersamaan sebagai bangsa untuk membangun Indonesia menuju masa depan yang lebih baik, di tengah persaingan dunia yang globalistik, tanpa harus kehilangan akar budaya dan nilai-nilai dasar Pancasila yang telah kita miliki. Sebagaimana yang tercantum dalam pasal 1 angka 1 Permendagri No.71 Tahun 2012 tentang Pedoman Pendidikan Wawasan Kebangsaan yaitu cara pandang bangsa Indonesia tentang diri dan lingkungannya mengutamakan persatuan dan kesatuan bangsa serta kesatuan wilayah yang dilandasi Pancasila, UUD Negara Republik Indonesia 1945, Bhinneka tunggal ika, dan Negara Kesatuan RI.
Wawasan kebangsaan meliputi mawas ke dalam dan mawas ke luar. Mawas ke dalam artinya memandang kepada diri bangsa Indonesia sendiri yang memiliki wilayah tanah air yang luas, jumlah penduduk yang banyak, keanekaragaman budaya dan lain-lain, harus diletakan dalam satu pandangan yang mendasarkan pada kepentingan bersama sebagai bangsa. Mawas ke luar, yaitu memandang terhadap lingkungan sekitar Negara-negara tetangga dan dunia internasional. Bangsa Indonesia harus memiliki integritas dan kredibilitas yang kuat dalam memainkan perannya di dunia internasional sebagai bangsa yang berdaulat dan bermartabat. Wildan mengemukakan bahwa:

Wawasan Kebangsaan pada hakikatnya adalah kesamaan persepsi dari segenap komponen bangsa Indonesia sebagai dasar bagi terbangunnya rasa dan semangat nasional yang tinggi dalam semua aspek kehidupan nasional. Wawasan Kebangsaan akan menjadi daya dorong untuk berbuat, mempersembahkan, dan mendarmabaktikan karya terbaik bagi bangsa dan negara. Lebih dari itu, hakikat Wawasan Kebangsaan menghendaki dimilikinya sikap untuk segera mengakhiri kesetiaan terhadap kelompok (partai, golongan, suku bangsa) atau perseorangan begitu kesetiaan terhadap bangsa dan negara diperlukan (2009, hlm.154 dalam Tim Sosialiasi Wawasan Kebangsaan Sekretariat Wakil Presiden RI, 2005, hlm.32).

Siswono (1996, hlm.17) mengemukakan bahwa "semangat dan wawasan kebangsaan menjadi penting untuk ditumbuh-kembangkan, karena rasa kebangsaan sebagai manifestasi dari rasa cinta pada tanah air, pada gilirannya membangkitkan kesadaran kita akan arti mahal dan bernilainya rasa kesatuan dan persatuan bangsa ini". Sebagaimana diungkapkan oleh Lemhanas (2013, hlm.31) : 
Wawasan kebangsaan sebagai salah satu aktualisasi nilai-nilai dasar kebangkitan nasional perlu ditularkan kepada seluruh rakyat Indonesia lintas generasi untuk memperkokoh ketahanan bangsa di era globalisasi. Hal ini dikarenakan Wawasan Kebangsaan adalah cara pandang bangsa Indonesia berdasarkan Pancasila dan Undang- Undang Dasar Negara Republik Indonesia Tahun 1945 tentang diri dan lingkungannya dalam mengekspresikan jati diri bangsa di tengah tatanan kehidupan dunia. Wawasan Kebangsaan juga mencerminkan hasrat bangsa Indonesia sebagai bangsa yang merdeka, bersatu, berdaulat, adil dan makmur dalam kebersamaan untuk mengatasi semua hambatan dan tantangan, baik dari luar maupun dari dalam negeri, termasuk rasa kebersamaan dalam menghadapi ancaman separatisme dan radikalisme yang dapat membahayakan persatuan dan kesatuan bangsa.

Maliki (2010, hlm.179) mengungkapkan "pengembangan wawasan kebangsaan adalah sesuatu yang sangat penting dalam upaya membangun kohesi sosial ditengah warga bangsa yang majemuk dan apalagi tengah dibayangi ancaman konflik etnis dan agama". Dengan demikian, wawasan kebangsaan menjadi penting untuk ditanamkan kepada setiap warga Warga Negara Indonesia, khususnya para mahasiswa, dan karena itu perlu disosialisasikan kepada segenap lapisan masyarakat secara terus menerus, bukan hanya sekedar menjadi sebuah gerakan sesaat, tetapi harus diupayakan secara berkesinambungan. Wawasan kebangsaan yang sering didengungkan oleh pemerintah, hendaknya tidak sekedar retorika verbal yang tak pernah diaktualisasikan dalam kenyataan. Namun wawasan kebangsaan harus benar-benar terealisasi dalam kehidupan nyata sehari-hari.

Wawasan kebangsaan Indonesia mengamanatkan kepada seluruh bangsa agar menempatkan persatuan, kesatuan, serta kepentingan dan keselamatan bangsa dan negara di atas kepentingan pribadi dan golongan. Diharapkan manusia Indonesia sanggup dan rela berkorban untuk kepentingan bangsa. Berkaitan dengan itu hendaknya dipupuk penghargaan terhadap martabat manusia, cinta kepada tanah air dan bangsa. Wawasan kebangsaan mengembangkan persatuan Indonesia sedemikian rupa sehingga asas Bhinneka tunggal ika dipertahankan. Persatuan tidak boleh mematikan keanekaan dan kemajemukan. Sebaliknya keanekaan dan kemajemukan tidak boleh menjadi pemecah belah namun menjadi kekuatan yang memperkaya persatuan.

Sedangkan semangat nasionalisme yang juga harus dimiliki oleh mahasiswa yaitu "semangat kebersamaan untuk membangun masa depan yang lebih sejahtera bagi seluru warga negara Indonesia, dengan tidak membedakan suku, agama, ras, warna kulit, gender atau golongan" (Lemhanas, hlm.107).

\section{Korelasi Pendidikan Kewarganegaraan dengan Peningkatan Wawasan Kebangsaan dan Semangat Nasionalisme Mahasiswa di Lingkungan STKIP Garut}

Hasil penelitian menunjukkan bahwa hipotesis yang berbunyi: "Terdapat korelasi yang signifikan antara mata kuliah PKn dengan peningkatan wawasan kebangsaan dan semangat nasionalisme mahasiswa di lingkungan STKIP Garut" telah diterima. Hal ini dapat dilihat dari hasil pengolahan data yang menunjukkan adanya tingkat keberartian antaravariabel X (mata kuliah PKn) terhadap variabel $Y_{1}$ (wawasan kebangsaan) dan variabel $\mathrm{Y}_{2}$ (semangat nasionalisme).

Hasil penelitian berdasarkan rumus korelasi yang digunakan Product Moment Coefficient (Pearson's Coefficient Of Correlation) menunjukkan angka $\mathrm{r}_{\mathrm{xy}}$ sebesar 0,694 dan 0,689. Berdasarkan kriteria 
penafsiran koefesien korelasi yang tertera pada tabel angka tersebut berada pada kategori kuat yakni berada pada rentang $0,60-0,799$.

Angka yang dihasilkan melalui rumus korelasi ini juga diolah kembali dengan rumus pengujian determinasi, dan sebagai hasilnya didapatlah nilai koefisien determinasi sebesar 43\% untuk variabel $\mathrm{X}$ (mata kuliah $\mathrm{PKn}$ ) dan $\mathrm{Y}_{1}$ (wawasan kebangsaan), $42 \%$ untuk variabel $\mathrm{X}$ (mata kuliah PKn) dan $\mathrm{Y}_{2}$ (semangat nasionalisme). Berdasarkan angka determinasi tersebut dapat disimpulkan bahwa mata kuliah PKn sebagai MKDU memberikan konstribusi yang signifikan terhadap pemahaman wawasan kebangsaan dan semangat nasionalisme mahasiswa di lingkungan STKIP Garut.

Besarnya angka koefisien determinasi pada penelitian ini tidak terlalu mengejutkan, karena sebagaimana kita pahami bahwa memang penerapan mata kuliah PKn di STKIP Garut berada dalam kategori sangat baik/sangat tinggi. Hal ini tidak begitu saja tertulis, melainkan telah menjadi pengamatan penulis jauh sebelum penelitian ini, namun dalam perspektif penulis sebagai mahasiswa yang diajarkan untuk menganalisa sesuatu secara ilmiah dan sistematis, maka penelitian ini dianggap perlu.

Hasil penelitian ini telah membuktikan bahwa penerapan mata kuliah PKn sebagai MKDU berperan penting bagi peningkatan wawasan kebangsaan dan semangat nasionalisme mahasiswa STKIP Garut. Hal ini sangat masuk akal karena sebagaimana telah disampaikan pada bab sebelumnya bahwa materi yang berkaitan dengan wawasan kebangsaan dan semangat nasionalisme sudah terintegrasi dalam perkuliahan mata kuliah pendidikan kewarganegaraan, sehingga disadari atau tidak, keterlibatan penerapan perkuliahan tersebut akan mempengaruhi terhadap peningkatan wawasan kebangsaan dan semangat nasionalisme mahasiswa di lingkungan STKIP Garut.

Berdasarkan temuan penelitian secara keseluruhan maka rumusan masalah pada penelitian ini telah terjawab. Hal tersebut menunjukkan pula bahwa mata kuliah pendidikan kewarganegaraan di STKIP Garut memiliki peranan yang penting guna meningkatkan pemahaman akan wawasan kebangsaan dan semangat nasionalisme mahasiswa di lingkungan sekolah tinggi keguruan dan ilmu pendidikan garut.

Pendidikan kewarganegaraan (citizenship education) memiliki peran penting dalam suatu kehidupan berbangsa dan bernegara. Pendidikan kewarganegaraan di Indonesia juga berkontiribusi penting dalam menunjang tujuan bernegara Indonesia. Pendidikan kewarganegaraan secara sistematik adalah dalam rangka perwujudan fungsi dan tujuan pendidikan nasional berdasarkan Pancasila dan UUD NRI 1945 Pendidikan kewarganegaraan berkaitan dan berjalan seiring dengan perjalanan pembangunan kehidupan berbangsa dan bernegara. Pendidikan kewarganegaraan merupakan bagian integral dari ide, instrumentasi, dan praksis kehidupan bermasyarakat, berbangsa, dan bernegara Indonesia (Udin Winataputra, 2008). Bahkan dikatakan, pendidikan nasional kita hakikatnya adalah pendidikan kewarganegaraan agar dilahirkan warga negara Indonesia yang berkualitas baik dalam disiplin sosial dan nasional, dalam etos kerja, dalam produktivitas kerja, dalam kemampuan intelektual dan profesional, dalam tanggung jawab kemasyarakatan, kebangsaan, kemanusiaan serta dalam moral, karakter dan kepribadian (Soedijarto, 2008).

Pendidikan kewarganegaraan di manapun pada dasarnya bertujuan membentuk warga negara yang baik (good citizen) (Somantri, 2001; Aziz Wahab, 2007; 
Kalidjernih, 2010). Namun konsep "warga negara yang baik" berbeda-beda dan sering berubah sejalan dengan perkembangan bangsa yang bersangkutan. Dalam konteks tujuan pendidikan nasional dewasa ini, warga negara yang baik yang gayut dengan pendidikan kewarganegaraan adalah warga negara yang demokratis bertanggung jawab (Pasal 3) dan warga negara yang memiliki semangat kebangsaan dan cinta tanah air (pasal 37 Undang-Undang No 20 Tahun 2003). Dapat disimpulkan bahwa tujuan pendidikan kewarganegaraan di Indonesia adalah membentuk warga negara yang demokratis bertanggung jawab, memiliki semangat kebangsaan dan cinta tanah air.

Sebagaimana yang tercantum dalam UU No.20 Tahun 2003 tentang Sistem Pendidikan Nasional yang merupakan landasan operasional dari pendidikan kewarganegaran di Indonesia. Dalam Pasal 37 (1) dikemukakan bahwa kurikulum pendidikan dasar dan menengah wajib memuat : “.. b. Pendidikan kewarganegaraan; ..." dan pada ayat (2) dikemukakan bahwa kurikulum pendidikan tinggi wajib memuat:..." b. Pendidikan kewarganegaraan; ...”. Sedangkan pada bagian penjelasan Pasal 37 dikemukakan bahwa "Pendidikan kewarganegaraan dimaksudkan untuk membentuk peserta didik menjadi manusia yang memiliki rasa kebangsaan dan cinta tanah air".

Adanya ketentuan tentang pendidikan kewarganegaraan dalam UU Sisdiknas sebagai mata pelajaran wajib di jenjang pendidikan dasar, menengah, dan tinggi menunjukkan bahwa mata pelajaran atau mata kuliah ini menempati kedudukan yang strategis dalam mencapai tujuan pendidikan nasional di negara ini. Adapun arah pengembangannya hendaknya difokuskan pada pembentukan peserta didik agar menjadi manusia Indonesia yang memiliki rasa kebangsaan dan cinta tanah air. Dari penjelasan di atas dapat kita ketahui bahwa pendidikan kewarganegaraan memiliki landasan yang kuat untuk dibelajarkan kepada setiap warga negara.

Pendidikan Kewarganegaraan (PKn) sebagai nama mata kuliah di perguruan tinggi merupakan perwujudkan dari pendidikan kewarganegaraan (PKn) dalam dimensi kurikuler khususnya kegiatan intra kurikuler. Pendidikan Kewarganegaraan di perguruan tinggi dimunculkan sebagai mata kuliah tersendiri, tidak terintegrasi dengan mata kuliah lain. Jika merujuk pada tujuan pendidikan nasional dan tujuan pendidikan kewarganegaraan yang terdapat dalam Undang-Undang No 20 Tahun 2003, maka terungkap bahwa fungsi pendidikan kewarganegaraan di perguruan tinggi adalah sebagai pendidikan demokrasi dan pendidikan kebangsaan. Sebagai pendidikan demokrasi karena bertujuan membentuk warga negara yang demokratis dan bertanggung jawab (pasal 3), dan sebagai pendidikan kebangsaan karena bertujuan membentuk warga negara yang memiliki semangat kebangsaan dan cinta tanah air (pasal 37). Jika demikian, dengan sederhana dapat disimpulkan bahwa mata kuliah Pendidikan Kewarganegaraan (PKn) memuat fungsi sebagai pendidikan demokrasi, pendidikan kebangsaan. Fungsi dari mata kuliah tersebut sekaligus menunjukkan jatidiri mata kuliah yang bersangkutan.

Sebagai kelompok mata kuliah pengembangan kepribadian yang memberi orientasi bagi mahasiswa dalam memantapkan wawasan dan kesadaran kebangsaan, cinta tanah air, demokrasi , penghargaan atas keragamaan dan partisipasinya membangun bangsa berdasar Pancasila. Sebagai kelompok mata kuliah pengembangan kepribadian yang menyelenggarakan pendidikan kebangsaan, demokrasi, 
HAM, multikulural dan kewarganegaraan kepada mahasiswa guna mendukung terwujudnya warga negara yang cerdas, terampil dan berkarakter sehingga dapat diandalkan guna membangun bangsa dan negara berdasar Pancasila dan UUD 1945 sesuai dengan bidang keilmuan dan profesinya.

Adapun yang menjadi tujuan dari pendidikan kewarganegaraan di perguruan tinggi yaitu : a) Memiliki wawasan dan kesadaran kebangsaan dan rasa cinta tanah air sebagai perwujudan warga negara Indonesia yang bertanggung jawab atas kelangsungan hidup bangsa dan Negara; b) Memiliki wawasan dan penghargaan terhadap keanekaragaman masyarakat Indonesia sehingga mampu berkomunikasi baik dalam rangka meperkuat integrasi nasional; c) Memiliki wawasan, kesadaran dan kecakapan dalam melaksanakan hak, kewajiban, tanggung jawab dan peran sertanya sebagai warga negara yang cerdas, trampil dan berkarakter; d) Memiliki kesadaran dan penghormatan terhadap hak-hak dasar manusia serta kewajiban dasar manusia sehingga mampu memperlakukan warga negara secara adil dan tidak diskriminatif; e) Berpartisipasi aktif membangun masyarakat Indonesia yang demokratis dengan berlandaskan pada nilai dan budaya demokrasi yang bersumber pada Pancasila; f) Memiliki pola sikap, pola pikir dan pola perilaku yang mendukung ketahanan nasional serta mampu menyesuaikannya dengan tuntutan perkembangan zaman demi kemajuan bangsa.

Dalam era globalisasi sekarang ini, pendidikan kewarganegaraan merupakan salah satu jawaban untuk mencetak kader-kader bangsa yang memiliki pemahaman akan wawasan kebangsaan dan juga semangat nasionalisme dalam rangka untuk memecahkan persoalan kebangsaan yang semakin kompleks. Bakri (2008:10) bahwa:
Melalui pendidikan kewarganegaraan, warga negara Republik Indonesia diharapkan mampu memahami, menganalisis, dan menjawab masalah-masalah yang dihadapi oleh masyarakat, bangsa dan negaranya secara berkesinambungan dan konisten cita-cita dan tujuan nasional seperti yang digariskan dalam pembukaan UUD 1945.

Berkaitan hal terebut Winataputra mengemukakan bahwa (2014):

Secara holistic pendidikan kewarganegaraan bertujuan agar setiap warga Negara muda (young citizens) memiliki rasa kebangsaan dan cinta tanah air dalam konteks nilai dan moral Pancasila, nilai dan norma Undang-Undang Dasar Negara Republik Indonesia Tahun 1945, nilai dan komitmen Bhinneka tunggal Ika, dan komitmen bernegara kesatuan Republik Indonesia. Oleh karena itu secara sadar dan terencana peserta didik sesuai dengan perkembangan psikologis dan konteks kehidupannya secara sistemik difasilitasi untuk belajar berkehidupan demokrasi secara utuh, yakni belajar tentang demokrasi (learning about democracy), belajar dalam iklim dan melalui proses demokrasi (learning through democracy), dan belajar untuk membangun demokrasi (learning for democracy).

Pendidikan Kewarganegaraan merupakan salah satu bidang kajian dalam konteks pendidikan nasional yang memiliki peran strategis untuk meningkatkan kembali wawasan kebangsaan dan semangat nasionalisme mahasiswa. Karena itu, untuk memperkuat peran Pendidikan Kewarganegaraan, maka pemerintah mewajibkan Pendidikan Kewarganegaraan diberikan pada setiap satuan pendidikan termasuk perguruan tinggi. Sebagaimana terdapat dalam pasal 37 ayat (1) Undang-Undang No.20 Tahun 2003 tentang Sistem Pendidikan Nasional bahwa "Pendidikan Kewarganegaraan dimaksudkan untuk membentuk peserta didik menjadi 
manusia yang memiliki rasa kebangsaan dan cinta tanah air". Oleh karena itu negara bertanggung jawab untuk mempersiapkan generasi muda/mahasiswa yang memiliki wawasan kebangsaan yang tinggi dan juga memiliki semangat nasionalisme dalam kehidupan berbangsa dan bernegara.

Pendidikan kewarganegaraan di perguruan tinggi merupakan sumber nilai dan pedoman dalam pengembangan dan penyelengaraan program studi, guna mengantarkan mahasiswa memantapkan kepribadiannya sebagai manusia seutuhnya. Hal ini berdasarkan pada suatu realitas yang dihadapi, bahwa mahasiswa adalah sebagai generasi bangsa yang harus memiliki visi intelektual, religius, berkeadaban, berkemanusiaan dan cinta tanah air dan bangsanya. Dengan adanya mata kuliah Pendidikan Kewarganegaraan diharapkan dapat membantu mahasiswa memantapkan kepribadiannya, agar secara konsisten mampu mewujudkan nilai-nilai dasar Pancasila, rasa kebangsaan dan cinta tanah air dalam menguasai, menerapkan dan mengembangkan ilmu pengetahuan, teknologi dan seni dengan rasa tanggung jawab dan bermoral. Berkaitan dengan itu mahasiswa diharapkan akan mampu untuk menjaga dan meneruskan cita-cita pembangunan bangsa dengan sungguh-sungguh mencintai bangsanya sendiri, dengan tidak membeda-bedakan setiap suku, ras, maupun agama yang mendiami di bumi pertiwi Indonesia. Dengan wawasan kebangsaan dan juga semangat nasionalisme maka hal ini diharapkan agar kita dapat menjaga keutuhan Negara Kesatuan Negara Indonesia agar tidak terpecah belah.

\section{PENUTUP}

Merujuk kepada hipotesis penelitian yang diajukan, maka secara umum kesimpulan penelitian ini adalah penerapan mata kuliah
Pendidikan Kewarganegaraan sebagai mata kuliah dasar umum yang tergabung dalam mata kuliah pengembangan kepribadian di perguruan tinggi yang diterapkan di lingkungan Sekolah Tinggi Keguruan dan Ilmu Pendidikan Garut memiliki keeratan hubungan yang kuat dan memberikan kontribusi yang besar dalam peningkatan wawasan kebangsaan dan semangat nasionalisme bagi mahasiswanya. Secara khusus kesimpulan penelitian ini sebagai berikut: 1) Penerapan mata kuliah pendidikan kewarganegaraan sebagai Mata Kuliah Dasar Umum yang tergabung dalam Mata Kuliah Pengembangan Kepribadian yang diterapkan di Sekolah Tinggi Keguruan dan Ilmu Pendidikan Garut sudah dilaksanakan dengan baik dan mampu memberikan kontribusi yang besar sebagaimana tujuan dari mata kuliah Pendidikan Kewarganegaraan itu sendiri; 2) Mahasiswa di lingkungan Sekolah Tinggi Keguruan dan Ilmu Pendidikan Garut memiliki pemahaman wawasan kebangsaan dan semangat nasionalisme yang sangat baik; 3) Penerapan mata kuliah pendidikan kewarganegaraan sebagai mata kuliah dasar umum memiliki hubungan yang kuat dan berpengaruh signifikan terhadap peningkatan semangat nasionalisme mahasiswa di lingkungan STKIP Garut.

Berdasaran kesimpulan hasil uji hipotesis penelitian di atas, maka dirumuskan beberapa kesimpulan hasil penelitian sebagai berikut: Pertama, kondisi penerapan mata kuliah pendidikan kewarganegaraan sebagai mata kuliah dasar umum, kondisi pemahaman wawasan kebangsaan dan semangat mahasiswa di lingkungan Sekolah Tinggi Keguruan dan Ilmu Pendidikan Garut termasuk pada kategori baik dengan klasifikasi yang sudah ditentukan sebelumnya. Kedua, keeratan masing-masing variabel mata kuliah pendi- 
dikan kewarganegaraan terhadap peningkatan wawasan kebangsaan dan semangat nasionalisme mahasiswa di lingkungan STKIP Garut bervariasi.

\section{DAFTAR PUSTAKA}

Arif, D. B. (2011). Pendidikan Kewarganegaraan Untuk Pembangunan Karakter Bangsa: Prospek dan Tantangan di Tengah Masyarakat yang Multikultural. Retrieved May 19, 2011 from http: Arifarif.wordpress.com/publikasi/

Arikunto, S. (2005). Prosedur Penelitian. Jakarta: Rineka Cipta.

Kountur, Ronny. (2009). Metode Penelitian untuk Penulisan Skripsi dan Tesis. Jakarta : PPM.

Lemhanas. (2013). Aktualisasi Semangat Kebangkitan Nasional Guna Memantapkan Wawasan Kebangsaan Lintas Generasi dalam Rangka Ketahanan Nasional. Jurnal Kajian Lemhannas RI, Edisi 15, hal : 30-40.

Lemhanas. (2012). Memperkokoh Nilai-Nilai Pancasila di Seluruh Komponen Bangsa untuk Memantapkan Semangat Kebanngsaan dan Jiwa Nasionalisme KeIndonesiaan dalam Rangka Menangkal Ideologi Radikalisme Global. Jurnal Kajian Lemhannas RI, Edisi 14, hal :97121.

Mahpudz, Asep. (2006). Pendidikan Nilai Moral Dalam Dimensi Pendidikan Kewarganegaraan (Menyambut 70 Tahun Prof. Drs. H.A Kosassih Djahiri). Laboratorium Pendidikan Kewarganegaraan (PKn). UPI Bandung : FPIPS.

Maliki, Zainuddin. (2010). Sosiologi Politik: Makna Kekuasaan dan Transformasi Politik. Yogyakarta: Gajah Mada University Press

Muhidin, Ali dan Abdurahman, Maman. (2007). Analisis Korelasi, Regresi, dan Jalur dalam Penelitian. Bandung:Pustaka Setia

Nazir, Moh. (2005). Metode Penelitian. Bogor : Ghalia Indonesia
Sapriya. (2012, April). Memperkokoh Posisi Pendidikan Kewarganegaraan Sebagai Disiplin Ilmu Terintegrasi. Disampaikan dalam Pidato Pengukuhan sebagai Guru Besar/Profesor dalam Bidang Pendidikan Kewarganegaraan pada FPIPS 26 April 2012. Bandung: Universitas Pendidikan Indonesia.

Sudjana, Nana dan Ibrahim. (2007). Penelitian dan Penilaian Pendidikan. Bandung : Sinar Baru Algesindo.

Sugiono. (2010). Metode Penelitian Kuantitatif Kualitatif dan $R \& D$. Bandung: Penerbit Alfabeta.

Syaodih, Nana. (2007). Metode Penelitian Pendidikan. Bandung : PT. Rosda Karya Remaja..

Wahab, Abdul Aziz dan Sapriya. (2011). Teori dan Landasan Pendidikan Kewarganegaraan. Bandung: Alfabeta.

Wildan, Dadan. (2009). Pendidikan Wawasan Kebangsaan di Era Reformasi Gelombang Kedua Untuk Mewujudkan Visi Indonesia 2015. Jurnal Sekretariat Negara Republik Indonesia, (14), hal :150-164.

Winataputra, U.S., \& Budimansyah, D. (eds). (2012). Pendidikan Kewarganegaraan dalam Perspektif Internasional: Konteks, Teori, dan Profil Pembelajaran. Bandung: Widya Aksara Press.

Winataputra, Udin S. (2014). Pendidikan Kewarganegaraan dalam Perspektif Internasional. Jurnal Acta Civicus, Vol 1 Edisi Oktober (1).

Winataputra, U.S. (2001). Jatidiri Pendidikan Kewarganegaraan sebagai Wahana Sistemik Pendidikan Demokrasi: Suatu Kajian Konseptual dalam Konteks Pendidikan IPS. Disertasi pada PPS UPI, tidak diterbitkan.

Wilodati. (2010) . Unity and National Harmony Dalam Bingkai Bhinneka Tunggal Ika. Jurnal Sekretariat Negara Republik Indonesia, (16), hal : 150-173.

Winataputra, U.S. (2005). Pendidikan Kewarganegaraan untuk Membangun Masyarakat Demokratis dan Berkeadaban: Tinjauan FilosofisPedagogis Makalah disampaiakan dalam Seminar dan Lokakarya Dosen 
Pendidikan Kewarganegaraan PTN dan $P T S$, Ditjen Dikti, untuk Wilayah Indonesia Barat. Hotel Dharma Deli, Medan 22 September 2005.

Winataputra, U.S. (2008). Pendidikan Kewarganegaraan Sebagai Suatu Sistem Pengetahuan Terpadu Academic Positioning Dari RUU Pendidikan Kewarganegaraan. Disajikan dalam Seminar Terbatas RUU Pendidikan Kewarganegaraan dalam Kebijakan Pertahanan 16 Oktober 2008. Jakarta: Dephan Ditjen Pothan.

Winataputra, U.S. (2014). Diskursus Aktual Tentang Paradigma Pendidikan
Kewarganegaraan (PKn) Dalam Konteks Kurikulum 2013. Bahan Diskusi dalam Semnas PKn-AP3KnI.

Surat Keputusan Dirjen Dikti No. 43/Dikti/2006 tentang Rambu-rambu Pelaksanaan Mata Kuliah pengembangan Kepribadian di Perguruan Tinggi.

Undang-Undang Dasar Negara Republik Indonesia Tahun 1945

Undang-Undang No.20 Tahun 2003 tentang Sistem Pendidikan Nasional.

Permendagri No.71 Tahun 2012 tentang Pedoman Pendidikan Wawasan Kebangsaan 